\title{
建筑工程施工绿色施工技术研究
}

\author{
咸国宝 \\ 中核（江苏）绿色建筑产业发展有限公司，江苏淮安 223001
}

[摘要] 传统建筑工程施工中人们对施工时的污染、建筑工程的功能一直有所不满, 这种现象发展至现代愈发明显, 随之为了 满足现代人的需求，现代建筑工程开始提倡绿色施工技术。绿色施工技术大体可以分为三个种类，即污染治理或防控技术、 建筑节能工艺技术、建筑材料管理技术, 这些技术对建筑工程施工有巨大帮助, 因此值得推广。对此文章将展开相关研究, 阐述各类绿色施工技术的作用与应用方式。

[关键词]建筑工程; 施工; 绿色施工技术

DOI：10.33142/sca.v3i3.2043 中图分类号: TU74 文献标识码：A

\section{Research on Green Construction Technology of Engineering Construction}

XIAN Guobao

China Nuclear (Jiangsu) Green Building Industry Development Co., Ltd., Huai'an, Jiangsu, 223001, China

\begin{abstract}
People are dissatisfied with the pollution and function of construction engineering in traditional engineering. This phenomenon is becoming more and more obvious in modern times. In order to meet the needs of modern people, modern construction engineering began to advocate green construction technology. Green construction technology can be roughly divided into three categories, namely pollution control or prevention technology, building energy-saving technology, building material management technology. These technologies are of great help to the construction of projects, so they are worth promoting. In this paper, we will carry out relevant research and elaborate the role and application of various green construction technologies.
\end{abstract}

Keywords: construction engineering; construction; green construction technology

\section{引言}

绿色施工技术是现代提出的施工技术概念, 旨在任何建筑工程施工行为所带来的负面影响都要尽可能的低, 同时 建筑功能要具备节能性, 这种概念在现代人的需求推动下迅速在工程领域中普及, 但很多工程企业对此并不了解, 施 工时更愿意使用传统技术。因此对绿色施工技术在建筑工程施工中的应用进行分析, 具有让绿色施工技术融入到建筑 工程施工中, 优化施工过程的现实意义。

\section{1 各类绿色施工技术在建筑工程施工中的作用}

\section{1 污染治理或防控技术作用}

建筑工程施工会造成很多污染, 如噪音污染、粉尘污染、生活垃圾污染（因建筑工程施工耗时较长, 所以施工人 员一般会在工地上生活, 而生活产生的垃圾就可能造成污染), 这些污染现象对周边环境的影响很大, 如噪音污染会导 致周边人员正常生活或工作作息异常、粉尘污染对施工人员及周边人员的身体健康存在威胁、生活垃圾污染具有腐臭 特征, 不但会导致土地受到影响, 臭味也会影响到周边人员的生活起居。这一条件下, 针对各类污染就必须采用污染 治理或防控技术来进行处理, 即针对所有污染现象, 施工企业应当做好基础设施建设工作, 并对污染成因进行治理, 同时对某些必须受控的污染进行防控, 由此可避免污染影响, 具有绿色理念体现 ${ }^{[1]}$ 。

\section{2 建筑节能工艺技术作用}

传统建筑工程施工比较关注工程质量, 即工程的力学关系等稳固即可, 而这种现象导致了工程企业对建筑功能的 开发力度不足, 因此长期以来建筑工程的功能都比较薄弱, 使得人们在生活中对于各类电器更加依赖, 如传统建筑工 程的保温隔热功能弱, 使得室内温度变化较快, 这时人们就必须依赖空调来调节室内温度, 而这显然就造成了电能上 的损耗。这一条件下, 现代人对于能源消耗非常关注, 认为建筑工程应当具备节能功能, 尽可能降低人在生活中的电 器依赖程度, 使电能消耗降低, 对此通过建筑节能工艺技术可使建筑工程具备良好的节能功能, 以满足现代人需求。 


\section{3 建筑材料管理技术作用}

建筑工程施工中需要使用到很多材料, 这些材料与工程成本有密切关系, 且具有环境污染性, 因此在绿色施工理 念下, 工程企业应当采用建筑材料管理技术来避免其负面影响。该项技术的作用分为两个方面, 即要重视材料利用率, 过程中应当尽可能排除所有对利用率存在负面影响的因素, 如不规范施工行为导致的材料报废、材料存放不当导致的 材料变质等; 重视材料应用规划, 确保每个施工环节所使用的材料与施工所需高度吻合, 避免材料成本支出过大, 间 接降低材料利用率。

\section{2 各类绿色施工技术在建筑工程施工中的应用}

\section{1 污染治理或防控技术应用}

针对建筑工程施工中的各类污染, 要采用不同的污染治理或防控技术来进行处理, 对此下文将提出相关污染治理 或防控技术，并分析它们的应用方式。

(1) 噪音污染防控技术

噪音污染是建筑工程施工中难以避免的污染现象, 施工时各类设备的运作都会造成噪音, 使人不甚其烦, 因此针 对噪音污染我们只能进行防控。防控技术上, 建筑工程应当尽可能将施工时间放在白天, 在晚间则休息, 这样至少可 以避免噪音污染对人们正常起居的影响, 尽可能的降低了噪音污染的影响程度 ${ }^{[2]}$ 。此外, 如果建筑工程的施工现场比较 封闭, 则可以在围挡处安置一些隔音材料, 如泡沫等, 此举可以吸收噪音, 减低噪音污染, 但如果场地比较开放, 则 只能使用以上方法来进行防控。

(2) 粉尘污染

粉尘污染也是一种难以避免的污染现象, 施工时的混凝土、石粉等都属于粉尘, 受施工行为影响会飘散到空气中, 随之容易被人体吸入, 威胁到人体健康。针对这一污染也只能做到防控, 即施工时应当定期对现场洒水, 借助水雾将 各类粉尘物质带入到地面, 使得空气变得洁净, 但这种方法必须注意酒水时的水流量, 对此必须通过计算, 确保酒水 水雾能够将粉尘污染控制在合理高度, 否则防控失败。

(3) 生活垃圾污染

生活垃圾是一项可以被治理的污染, 需要现场人员对其进行全面管理。方法上首先要设置一个专门的生活垃圾处 理点, 应当在现场建设垃圾场, 其次对现场施工人员的生活行为进行管理, 要求他们将生活垃圾全部排放到垃圾场, 不可随意丢弃, 否则要对相关人员进行处罚, 最后有必要定期对垃圾场内垃圾进行处理, 处理技术可采用降解技术, 若遇到不可降解的垃圾, 则建议交于专门的机构进行处理。

\section{2 建筑节能工艺技术应用}

建筑节能工艺技术种类繁多，其中较具代表性的有保温隔热层工艺、采光工艺，各工艺技术应用方式见下文。

(1) 保温隔热层工艺

为了在冷热气温的变化下保持建筑室内温度稳定, 在建筑工程中可使用保温隔热层工艺, 该工艺分为两个步骤: (1)合理选择隔热保温材料, 如加气混凝土、珍珠岩、玻璃棉等, 此类材料本身就具有良好的隔热保温作用, 将其应用 于建筑工程施工中, 可以保障室内温度, 降低人们对电器的需求; (2)保温隔热层施工, 为了充分发挥各类保温隔热材 料的作用, 在施工中应当进行保温隔热层施工, 即在建筑外墙的内外两侧中间, 采用保温隔热材料进行布设, 形成一 个三层式的墙体结构, 这个结构可以对内部温度的流失、外部温度的导入进行控制, 可使室内温度稳定保持在一个合 理区间。

(2) 采光工艺

为了降低人们对照明电器的依赖程度, 在建筑施工中可以采用采光工艺来实现目的, 该工艺可分为两个步骤: (1) 合理选择采光材料, 如透明玻璃或有色玻璃等, 此类材料能够合理控制室内光强程度; (2)合理设置采光材料, 即在使 用采光材料进行施工时, 首先必须确认采光材料所安置的位置, 如棚顶、窗口等, 其次需要根据采光需要对采光材料 的角度进行设置, 确保采光合理。此外, 如果条件允许还可以借助智能技术对采光材料的采光角度进行控制, 实时根 
据室内外光照变化来调节角度, 充分发挥采光工艺的节能作用。

\section{3 建筑材料管理技术应用}

建筑材料管理技术的应用主要强调两个重点, 即材料存放与材料使用, 下文将对两个材料的管理要求进行分析。

(1) 材料存放管理要求

以建筑工程施工中常见的水泥、钢筋材料为例进行分析, 首先各类原料区分存放, 其中水泥要放置在干燥、干净 的环境当中, 以免水泥受外界因素影响而发生变质, 其次在钢筋存放时, 除了要将其放在干燥、干净的环境中以外, 还要保障钢筋存放垫木的厚度不低于 $20 \mathrm{~cm}$, 且存放过程中要合理堆放, 不可抛投, 否则容易导致钢筋损坏、变形。

(2) 材料使用管理要求

在建筑工程施工之前必须对各施工环节对各类材料的需求进行统筹, 随后根据统筹结果来分配材料。在材料使用 过程中, 必须安排专人对施工人员的行为规范性进行监督与管理, 尽可能避免材料浪费、损坏等现象, 此举不但有利 于工期成本, 还能降低材料污染、能源消耗, 具有良好的绿色理念表现。

\section{3 结语}

综上, 本文对建筑工程施工绿色施工技术进行了分析, 通过分析阐述了绿色施工技术的作用、应用方式。根据分 析可知, 绿色施工技术对于建筑工程施工而言意义重大, 能够全面管制施工污染现象、优化工程功能体系、提高材料 利用率，整体上可起到提高降低施工污染、节约能源消耗的作用。

\section{[参考文献]}

[1]午建民. 绿色施工技术在建筑工程中的应用 [J].教育教学论坛, 2014(49) : 114-115.

[2]林通. 民用建筑施工中绿色施工技术的应用研究 [J]. 江西建材, 2015 (21) : 111-112.

作者简介: 咸国宝 (1980.8 - ), 男, 毕业院校: 中国矿业大学, 现就职单位: 中核 (江苏) 绿色建筑产业发展有限公司。 